DOI: $10.15193 /$ zntj/2020/123/337

\author{
AGNIESZKA DUDKIEWICZ, BARTŁOMIEJ KOŹNIEWSKI, \\ ANNA SZYMAŃSKA
}

\title{
ZASTOSOWANIE SPEKTROSKOPII BLISKIEJ PODCZERWIENI DO ANALIZY WARTOŚCI ODŻYWCZEJ PRODUKTÓW GARMAŻERYJNYCH I MAKARONÓW DOSTĘPNYCH NA POLSKIM RYNKU
}

\begin{abstract}
Streszczenie
Celem pracy była ocena przydatności techniki spektroskopii bliskiej podczerwieni (NIR) do analizy wartości odżywczej produktów garmażeryjnych i makaronów dostępnych na polskim rynku. Ocenę przeprowadzono na podstawie porównania wyników wartości odżywczej podanych przez NIR z wynikami analiz laboratoryjnych. Urządzenie NIR skalibrowano w odniesieniu do trzech rodzajów produktów: 1) produkty garmażeryjne $z$ mięsem typu krokiety, pierogi, pyzy, tortille, 2) produkty garmażeryjne z serem typu pierogi z serem i ruskie, naleśniki z serem, leniwe, knedle z serem, 3) produkty garmażeryjne inne typu pyzy ziemniaczane, kopytka, kluski na parze, naleśniki bez dodatków, a także makarony po ugotowaniu. Kalibracje wykonano poprzez korelację widm NIR z wynikami analiz laboratoryjnych poszczególnych rodzajów produktów i składników chemicznych.

Wykazano, że jakość pomiaru była do zaakceptowania w odniesieniu do składników chemicznych: woda, białko, tłuszcz, węglowodany, składniki mineralne jako popiół, błonnik i kwasy tłuszczowe nasycone, przynajmniej w przypadku dwóch rodzajów produktów poddanych analizie. Dla żadnego z analizowanych rodzajów produktów nie uzyskano satysfakcjonujących wyników dotyczących cukrów (prostych i dwucukrów) oraz soli $(\mathrm{NaCl})$. Mała dokładność pomiaru NIR tych składników chemicznych mogła wynikać z niskiego lub mało zróżnicowanego poziomu badanej substancji, właściwego danemu rodzajowi produktu lub słabej interakcji danego składnika z promieniowaniem NIR, co utrudnia jego wykrycie. Na podstawie wyników można stwierdzić, że metoda NIR jest przydatna do poprawnej predykcji większości składników chemicznych składających się na wartość odżywczą, które należy deklarować na opakowaniach produktów garmażeryjnych i makaronów. Może stanowić dobrą alternatywę dla kosztownych i czasochłonnych analiz laboratoryjnych.
\end{abstract}

Słowa kluczowe: spektroskopia bliskiej podczerwieni (NIR), wartość odżywcza, produkty garmażeryjne, chemometria, kalibracja NIR

Dr inż. A. Dudkiewicz, dr inż. B. Koźniewski, mgr A. Szymańska, JARS S. A., Lajski, ul. Kościelna 2a, 05-119 Legionowo.Kontakt: a.dudkiewicz@ujd.edu.pl 


\section{Wprowadzenie}

Spektroskopia bliskiej podczerwieni (NIR) jest szeroko stosowana w przemyśle spożywczym. Świadczy o tym zarówno dostępność aparatów NIR przeznaczonych do analizy surowców i produktów spożywczych, jak i wzrastająca w ostatniej dekadzie liczba wydawanych norm ISO dotyczących zastosowania spektroskopii NIR do analizy składników chemicznych, np. tłuszczu, białka i wody w mięsie lub wilgotności i zawartości białka w ziarnie zbóż [20,22]. Metoda NIR charakteryzuje się wieloma zaletami w porównaniu z klasycznymi i instrumentalnymi technikami analizy chemicznej, rutynowo stosowanymi do oznaczania wartości odżywczej żywności. Do głównych zalet metody należą: brak zużycia próbki, szybkość oznaczania, minimalny wkład pracy w przygotowanie próbki, brak zużycia i utylizacji substancji chemicznych obciążających środowisko i stanowiących ryzyko dla zdrowia $[5,8,13]$. Pomimo takiej przewagi nad metodami stosowanymi w laboratoriach analitycznych, NIR cechuje się pewnymi ograniczeniami. Wymagana jest kalibracja uwzględniająca każdy rodzaj produktu, a do przeprowadzenia kalibracji potrzeba przynajmniej kilkudziesięciu próbek, w których poziom mierzonych właściwości jest znany. Ograniczenie to spowalnia poszerzanie stosowania metody zwłaszcza w przypadku złożonych produktów spożywczych, jakimi są np. produkty garmażeryjne.

Rynek produktów garmażeryjnych jest bardzo zróżnicowany i charakteryzuje się zmiennością geograficzną. Spożycie tych produktów wzrasta w krajach rozwiniętych, w tym w Polsce, a producenci w większości krajów są zobligowani do umieszczania informacji o wartości odżywczej produktu na jego etykiecie [25, 28]. Z kolei względy jakościowe przesądzają o konieczności monitorowania surowców i wyrobów w trakcie produkcji [10]. Wzrasta zatem zapotrzebowanie na szybkie i tanie metody analizy składu chemicznego produktów garmażeryjnych, takie jak NIR [9].

Widma NIR są złożonymi sygnałami elektromagnetycznymi pochodzącymi z wibracji wiązań chemicznych wzbudzonych przez promieniowanie w zakresie długości fali $780 \div 2500 \mathrm{~nm}$ [3]. Najwyraźniejsze pasma adsorpcyjne w widmie NIR odpowiadają wiązaniom wodoru $\mathrm{z}$ innymi lekkimi atomami, takimi jak węgiel, tlen czy azot, dlatego metodę często stosuje się do oznaczania białek i thuszczów, a także wody [5]. $\mathrm{Z}$ drugiej strony pomiar składników chemicznych nieorganicznych - chlorku sodu i związków mineralnych w postaci popiołu - za pomocą NIR może stwarzać problemy ze względu na brak interakcji z promieniowaniem w zakresie bliskiej podczerwieni. Zawartość tych substancji jest przewidywana pośrednio, np. poprzez inne komponenty wchodzące $\mathrm{w}$ interakcje $\mathrm{z}$ substancją mierzoną lub takie, których zawartość koreluje z zawartością substancji mierzonej [14]. Taki pośredni sposób detekcji może skutkować zmniejszeniem czułości metody. Czułość NIR stanowi problem przy oznaczaniu niektórych składowych wartości odżywczej wymienionych w rozporządzeniu UE $\mathrm{Nr}$ 1169/2011 [25]. Ogólnie przyjętą granicą oznaczalności dla metody jest $0,5 \%$ zawar- 
tości substancji mierzonej w próbce [17]. Oznacza to większą niepewność pomiaru i możliwy problem z oznaczeniem składników występujących w żywności zazwyczaj w małych ilościach, takich jak: sól $(\mathrm{NaCl})$, związki mineralne w postaci popiołu, kwasy tłuszczowe nasycone, błonnik i cukry.

W literaturze przedmiotu znajdują się raporty dotyczące oznaczania poszczególnych składników odżywczych z wykorzystaniem metody NIR, jednak w niewielu z nich skupiono się na pełnej charakterystyce wartości odżywczej produktów spożywczych w rozumieniu Rozporządzenia UE Nr 1169/2011 [25].

Celem niniejszej pracy była ocena przydatności techniki spektroskopii bliskiej podczerwieni (NIR) do analizy wartości odżywczej produktów garmażeryjnych i makaronów dostępnych na polskim rynku.

\section{Material i metody badań}

Do badań użyto 210 różnych próbek wyrobów garmażeryjnych i makaronów zakupionych w lokalnych sklepach spożywczych. Próbki zostały podzielone na 3 rodzaje produktów:

1) produkty garmażeryjne z mięsem typu krokiety, pierogi, pyzy, tortille (GM),

2) produkty garmażeryjne $z$ serem typu pierogi z serem i ruskie, naleśniki z serem, leniwe, knedle z serem (GS),

3) produkty garmażeryjne inne, typu pyzy ziemniaczane, kopytka, kluski na parze, naleśniki bez dodatków, a także makarony po ugotowaniu (GI).

Zakupione produkty były zarówno w postaci mrożonej, jak i gotowej do podgrzania lub spożycia.

Wszystkie próbki homogenizowano w młynku laboratoryjnym (GRINDOMIX GM 200, Retsch, Niemcy), a następnie poddawano badaniu metodą NIR przy użyciu

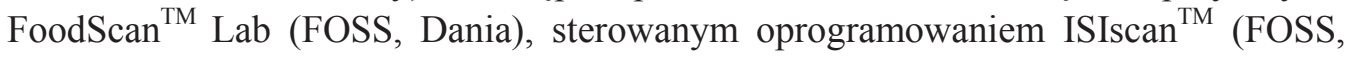
Dania). Do badań zastosowano kompatybilne z instrumentem kuwety ze szklanym okienkiem o średnicy $14 \mathrm{~cm}$. Kuwety wypełniano homogenną próbką o objętości ok. $120 \mathrm{~cm}^{3}$. Uzyskane widma mieściły się w zakresie długości fal $850 \div 1050 \mathrm{~nm}$.

Bezpośrednio po badaniu metodą NIR próbki przekazywano do analizy w akredytowanym laboratorium. Analizy były przeprowadzane metodami podanymi w tab. 1.

Po przypisaniu wartości składników oznaczonych w laboratorium do odpowiadających im widm NIR wykonywano chemometryczną obróbkę widm i kalibracje w programie WinISI 4 (FOSS, Dania). Kalibracje przeprowadzano wykorzystując 60 z 70 dostępnych próbek każdego rodzaju produktu. Dokonywano obróbki matematycznej Modified PLS (zmodyfikowana metoda cząstkowych najmniejszych kwadratów). Wykonano po cztery kalibracje każdego składnika chemicznego i każdego rodzaju produktu: jedną na widmie surowym, a trzy pozostałe na kolejnych pochodnych matematycznych. Przy wykonywaniu każdej kalibracji testowano również opcję odrzucenia 
punktów odstających poprzez monitorowanie wpływu takiej obróbki na parametry określające jakość otrzymywanych modeli matematycznych. Oceny i wyboru optymalnych kalibracji dokonywano na podstawie współczynnika determinacji $\left(\mathrm{R}^{2}\right)$ i średniego błędu kwadratowego predykcji NIR (RMSEP) dla zbioru prób kalibracyjnych. Wybrano kalibracje charakteryzujące się najwyższym $\mathrm{R}^{2}$ i najniższym RMSEP, które przedstawiono w niniejszej pracy.

Tabela 1. Zastosowane metody badań laboratoryjnych wraz z niepewnością pomiaru

Table 1. Applied methods of laboratory analyses including measurement uncertainty

\begin{tabular}{||c|c|c||}
\hline $\begin{array}{c}\text { Składnik chemiczny } \\
\text { Chemical component }\end{array}$ & $\begin{array}{c}\text { Źródło metody } \\
\text { Source of method }\end{array}$ & $\begin{array}{c}\text { Niepewność } \\
\text { rozszerzona } \\
\text { Expanded } \\
\text { uncertainty [\%] }\end{array}$ \\
\hline Woda / Water & PN-A-82100:1985 [19] & 10 \\
\hline Białko / Protein & PN-A-04018:1975 [18] & 5 \\
\hline Tłuszcz / Fat & PN-ISO 1444:2000 [24] & 10 \\
\hline Węglowodany / Carbohydrates & Rozporządzenie UE Nr 1169/2011 [25] & - \\
\hline Błonnik / Fibre & Metoda enzymatyczna [15] & 15 \\
\hline Cukry / Sugars & PN-A-82100:1985 [19] & 15 \\
\hline $\begin{array}{c}\text { Kwasy tłuszczowe nasycone } \\
\text { Saturated fatty acids }\end{array}$ & PN-EN ISO 12966-4:2015-07 [23] & 20 \\
\hline Popiół / Ash & PN-A-82100:1985 [19] & 15 \\
\hline $\begin{array}{c}\text { Sól / Salt } \\
\text { (NaCl) }\end{array}$ & Metoda ICP-OES [21] i Rozporządzenia & 10 \\
\hline
\end{tabular}

Objaśnienia / Explanatory notes:

Cukry i węglowodany w niniejszej pracy odpowiadają definicjom podanym w Rozporządzeniu UE nr 1169/2011 [25]. Przez cukry należy rozumieć cukry proste i dwucukry, natomiast węglowodany to cukry, alkohole wielowodorotlenowe i skrobia. / Sugars and carbohydrates in this study correspond with the definitions as outlined in the EU regulation No. 1169/2011 [25]. By sugars are meant simple sugars and disaccharides, while carbohydrates are sugars, polyols and starch. „Popiół” jako składnik chemiczny produktów jest sformułowaniem uproszczonym. Pod tym pojęciem należy rozumieć związki mineralne w postaci popiołu / „Ash” as a chemical component of the products is a simplistic term. This term should be understood as mineral compounds in the form of ash.

W celu porównania otrzymanych modeli matematycznych z kryteriami i danymi opublikowanymi w literaturze posłużono się błędem kwadratowym walidacji krzyżowej (RMSECV) i stosunkiem odchylenia standardowego (SD) mierzonych składników chemicznych do RMSEP (RPD).

Pozostałe 10 z 70 próbek, których nie użyto w kalibracji, stanowiło zbiór walidacyjny, na podstawie którego wyliczono poprawność metody: 


$$
\mathrm{U}_{\mathrm{p}}=2 \times \frac{\mathrm{SD}_{\mathrm{p}}}{\sqrt{\mathrm{n}}}
$$

gdzie:

$\mathrm{U}_{\mathrm{p}}$ - poprawność (jako niepewność rozszerzona),

$\mathrm{SD}_{\mathrm{p}}$ - odchylenie standardowe wartości poprawności pomiarów stanowiącej procentowy stosunek wartości wskazanej przez NIR do wartości zmierzonej w laboratorium, $\mathrm{n}$ - liczba próbek.

Poprawność została wyliczona po odrzuceniu z puli wyników danych, które wykraczały poza zakres analityczny. Zakres analityczny dla każdego rodzaju produktu i analizowanego składnika chemicznego został wyznaczony pomiędzy 10 i 90 percentylem wyników analiz laboratoryjnych użytych w kalibracji. Jeśli wartość 10 percentyla była mniejsza niż $0,5 \%$, to te $0,5 \%$ przyjmowano jako dolną granicę tego zakresu.

Uzyskane wyniki poprawności zostały wykorzystane do oceny przydatności metody NIR do analizy składników chemicznych składających się na wartość odżywczą w produktach garmażeryjnych i makaronach. Jako kryterium oceny przydatności przyjęto, że poprawność nie powinna przekraczać 150 \% wartości deklarowanej przez laboratorium dla niepewności rozszerzonej oznaczanego składnika chemicznego.

\section{Wyniki i dyskusja}

Wyniki analiz laboratoryjnych wraz z ustalonymi dla poszczególnych rodzajów produktów zakresami analitycznymi NIR przedstawiono w tab. 2. Średnia zawartość soli w produktach GI i GS nie przekraczała $0,5 \%$. We wszystkich pozostałych rodzajach produktów zawartość składników chemicznych wynosiła powyżej $0,5 \%$, a więc przekraczała ogólnie przyjętą dla metody NIR granicę oznaczalności [17].

Wartości parametrów, na których podstawie dokonano oceny kalibracji, przedstawiono w tab. 3. Zakres $\mathrm{R}^{2}$ otrzymanych kalibracji wynosił $0,102 \div 0,991$. Najwyższe wartości współczynników determinacji odnosiły się do wszystkich makroskładników, wody i kwasów tłuszczowych nasyconych $(\geq 0,865)$, natomiast najniższe - do błonnika $(0,102 \div 0,436)$. W przypadku popiołu i soli oraz cukrów w próbach GM i GI odnotowano pośrednie wartości $\mathrm{R}^{2}(0,631 \div 0,919)$, jedynie kalibracja cukrów w produktach GS charakteryzowała się $\mathrm{R}^{2}$ wyższym, tj. 0,941.

W źródłach literaturowych wartości współczynników determinacji makroskładników i różnych grup kwasów tłuszczowych w powiązaniu z widmami NIR są zwykle wysokie, powyżej $0,9[1,4$ - 6]. Tak wysokie wartości osiąga się również w przypadku analizy związków mineralnych w postaci popiołu w mięsie, ale w innych produktach, np. zbożowych - już niższe (przykładowo 0,653 w otrębach ryżowych i 0,730 w mące z komosy ryżowej) [2, 7]. Kalibracje NIR dotyczące błonnika, cukrów i soli także mogą charakteryzować się wysokimi wartościami $\mathrm{R}^{2}(>0,9)$. Większość danych literatu- 
rowych odnoszących się do takich przypadków bazuje jednak na produktach o dużej zawartości wymienionych składników, średnio ok. 5 - 10 razy większej niż w produktach garmażeryjnych użytych w niniejszych badaniach $[11,12,16,26]$. W niniejszej pracy zaobserwowano wpływ zawartości danego składnika chemicznego na wartość $\mathrm{R}^{2}$ danej kalibracji. Przykładem są cukry, a najwyższy współczynnik determinacji dotyczył produktów GS, w których średnia zawartość tego składnika była na poziomie niespełna dwukrotnie wyższym niż w pozostałych dwóch rodzajach produktów (tab. 2).

Tabela 2. Charakterystyka próbek trzech wybranych rodzajów produktów oraz wyznaczony zakres analityczny NIR

Table 2. Profile of samples of three selected groups of products and analytical range fixed for NIR

\begin{tabular}{|c|c|c|c|c|c|c|}
\hline \multirow{2}{*}{$\begin{array}{l}\text { Zawartość składników } \\
\text { chemicznych } \\
\text { Content of chemical } \\
\text { components [\%] }\end{array}$} & \multicolumn{2}{|c|}{ GM } & \multicolumn{2}{|c|}{ GS } & \multicolumn{2}{|c|}{ GI } \\
\hline & $\overline{\mathrm{X}} \pm \mathrm{SD}$ & Z & $\overline{\mathrm{X}} \pm \mathrm{SD}$ & Z & $\overline{\mathrm{X}} \pm \mathrm{SD}$ & Z \\
\hline Woda / Water & $57,3 \pm 8,0$ & $48,6 \div 69,2$ & $59,2 \pm 5,7$ & $52,3 \div 67,4$ & $62,4 \pm 10,4$ & $53,9 \div 72,8$ \\
\hline Białko / Protein & $8,2 \pm 3,2$ & $4,1 \div 12,1$ & $7,5 \pm 2,1$ & $4,9 \div 10,7$ & $4,4 \pm 2,6$ & $1,6 \div 8,4$ \\
\hline Thuszcz / Fat & $7,2 \pm 3,8$ & $3,3 \div 12,6$ & $3,0 \pm 1,7$ & $1,1 \div 4,8$ & $2,2 \pm 3,7$ & $0,5 \div 7,9$ \\
\hline $\begin{array}{l}\text { Węglowodany } \\
\text { Carbohydrates }\end{array}$ & $25,4 \pm 5,1$ & $19,8 \div 31,5$ & $29,4 \pm 4,6$ & $22,9 \div 36,1$ & $30,2 \pm 7,3$ & $22,6 \div 38,0$ \\
\hline Błonnik / Fibre & $2,3 \pm 0,7$ & $1,5 \div 3,5$ & $1,9 \pm 0,9$ & $1,0 \div 3,0$ & $2,3 \pm 1,0$ & $1,3 \div 3,8$ \\
\hline Cukry / Sugars & $2,2 \pm 1,8$ & $0,6 \div 4,8$ & $4,2 \pm 3,3$ & $0,9 \div 8,5$ & $2,5 \pm 3,3$ & $0,6 \div 6,5$ \\
\hline $\begin{array}{c}\text { Kwasy tłuszczowe } \\
\text { nasycone / Saturated } \\
\text { fatty acids }\end{array}$ & $2,3 \pm 1,1$ & $1,1 \div 3,8$ & $1,0 \pm 0,9$ & $0,5 \div 2,1$ & $0,8 \pm 1,6$ & $0,5 \div 2,2$ \\
\hline Popiół / Ash & $1,4 \pm 0,5$ & $0,8 \div 2,1$ & $1,0 \pm 0,5$ & $0,5 \div 1,7$ & $0,9 \pm 0,6$ & $0,5 \div 1,7$ \\
\hline Sól / Salt $(\mathrm{NaCl})$ & $0,7 \pm 0,4$ & $0,5 \div 1,2$ & $0,5 \pm 0,3$ & $0,5 \div 1,0$ & $0,4 \pm 0,4$ & $0,5 \div 1,0$ \\
\hline
\end{tabular}

Objaśnienia / Explanatory notes:

GM - produkty garmażeryjne z mięsem / deli products with meat; GS - produkty garmażeryjne z serem / deli products with quark; GI - produkty garmażeryjne inne / other deli products; $\overline{\mathrm{X}} \pm \mathrm{SD}$ - wartość średnia \pm odchylenie standardowe / mean value \pm standard deviation; $Z$ - zakres analityczny NIR / analytical range for NIR. Pozostałe objaśnienia jak pod tab. 1. / Other explanatory notes as in Tab. 1.

Wartości błędu kwadratowego walidacji krzyżowej (RMSECV) w przypadku wszystkich rodzajów produktów i składników chemicznych nie przekraczały $2 \%$. Inni autorzy opisują różne wyniki RMSECV, od znacznie poniżej 1 do nawet 5, jednak ważną cechą przy ewaluacji tego parametru jest jego stosunek do wartości mierzonej $[6,27]$. W niniejszej pracy wartości RMSECV nie przekraczały $20 \%$ wartości średniej 
wszystkich makroskładników i wody niezależnie od rodzaju produktu, natomiast dotyczące cukrów i soli przekraczały 30 \% wartości średniej.

Tabela 3. Parametry opisujące jakość wykonanych kalibracji

Table 3. Parameters descriptive of quality of calibrations performed

\begin{tabular}{|c|c|c|c|c|c|c|c|c|c|c|c|c|}
\hline \multirow{2}{*}{$\begin{array}{l}\text { Składnik } \\
\text { chemiczny } \\
\text { Chemical } \\
\text { component }\end{array}$} & \multicolumn{3}{|c|}{$\mathrm{R}^{2}$} & \multicolumn{3}{|c|}{ RMSECV [\%] } & \multicolumn{3}{|c|}{$\begin{array}{c}\text { RPD [kalibracja] } \\
\text { [calibration] }\end{array}$} & \multicolumn{3}{|c|}{$\begin{array}{c}\text { RPD [walidacja] } \\
\text { [validation] }\end{array}$} \\
\hline & I & II & III & I & II & III & I & II & III & I & II & III \\
\hline Woda / Water & 0,985 & 0,961 & 0,991 & 1,02 & 1,27 & 1,54 & 2,3 & 5,0 & 10,5 & 5,9 & 2,6 & 3,1 \\
\hline Białko / Protein & 0,920 & 0,964 & 0,957 & 1,06 & 0,47 & 0,80 & 3,5 & 5,3 & 4,8 & 7,1 & 2,5 & 0,6 \\
\hline Tłuszcz / Fat & 0,972 & 0,980 & 0,976 & 068 & 0,26 & 0,42 & 17,2 & 5,7 & 6,5 & 8,5 & 2,3 & 2,5 \\
\hline $\begin{array}{l}\text { Węglowodany } \\
\text { Carbohydrates }\end{array}$ & 0,946 & 0,928 & 0,970 & 1,39 & 1,49 & 1,46 & 4,3 & 3,7 & 1,7 & 2,9 & 4,2 & 2,7 \\
\hline Błonnik / Fibre & , & 0,4 & 0,102 & 0,00 & 0,56 & 0,62 & 1,2 & 1,2 & 1,0 & 0,9 & 0,5 & 0,7 \\
\hline Cukry / Sugars & 0,674 & 0,941 & 0,631 & 1,44 & 1,28 & 1,76 & 1,7 & 2,6 & 1,5 & 1,4 & 1,2 & 1,5 \\
\hline $\begin{array}{c}\text { Kwasy tłuszczowe } \\
\text { nasycone } \\
\text { Saturated fatty } \\
\text { acids } \\
\end{array}$ & 0,905 & 0,914 & 0,975 & 0,41 & 0,25 & 0,48 & 3,2 & 4,3 & 6,1 & 4,3 & 0,9 & 0,6 \\
\hline Popiół / Ash & 0,738 & 0,866 & 0,919 & 0,30 & 0,21 & 0,31 & 2,0 & 2,7 & 3,6 & 1,1 & 1,0 & 0,4 \\
\hline Sól / Salt (NaCl) & 0,683 & 0,869 & 0,861 & 0,29 & 0,15 & 0,19 & 1,8 & 2,7 & 1,4 & 0,6 & 0,6 & 0,3 \\
\hline
\end{tabular}

Objaśnienia / Explanatory notes:

I - produkty GM / GM products, II - produkty GS / GS products, III - produkty GI / GI products. $\mathrm{R}^{2}-$ współczynnik determinacji / coefficient of determination, RMSECV - błąd kwadratowy walidacji krzyżowej / mean squared error of cross-validation, RPD - stosunek odchylenia standardowego do średniego błędu kwadratowego predykcji / ratio of the standard deviation to the mean squared error of the prediction. Pozostałe objaśnienia jak pod tab. 1. i 2. / Other explanatory notes as in Tab. 1 and 2.

Oceny jakości kalibracji można dokonać na podstawie wartości parametru RPD. W literaturze sugeruje się, że kalibracje charakteryzujące się RPD w zakresie $2,5 \div 5$ mogą być wykorzystywane do wykrywania danej substancji (klasa I), $5 \div 10$ - do aplikacji przy kontroli jakości (klasa II), > 10 - charakteryzują się bardzo dużą zdolnością do predykcji zawartości mierzonej cechy lub substancji (klasa III) [11]. Zgodnie z przyjętymi kryteriami, na podstawie RPD wyliczonych dla kalibracji, uzyskano dwie kalibracje klasy III, pięć kalibracji klasy II i dziesięć kalibracji klasy I. Pozostałe dziewięć kalibracji charakteryzowało się wartościami RPD $<2,5$. Małe wartości RPD zarówno w zbiorze prób kalibracyjnych, jak i walidacyjnych dotyczyły głównie składników chemicznych, które występowały w produktach garmażeryjnych na poziomach do kilku procent. W innych badaniach autorzy również otrzymywali małe wartości RPD modeli ocenionych pozytywnie, np. 1,7 - w przypadku kalibracji NIR służącej do pomiaru zawartości białka w koncentratach białek serwatkowych [27]. RPD zależy nie 
tylko od błędu kalibracji, ale również od odchylenia standardowego oznaczanych parametrów. Jeśli badany parametr charakteryzuje się niewielką zmiennością, to RPD nie jest obiektywnym wskaźnikiem jakości kalibracji. W niniejszej pracy oceniono zatem użyteczność metody NIR do pomiaru komponentów wartości odżywczej produktów garmażeryjnych i makaronów poprzez porównanie poprawności pomiarów prób walidacyjnych z kryterium oszacowanym na podstawie niepewności rozszerzonej deklarowanej przez laboratorium. Wyniki przedstawiono na rys. 1.

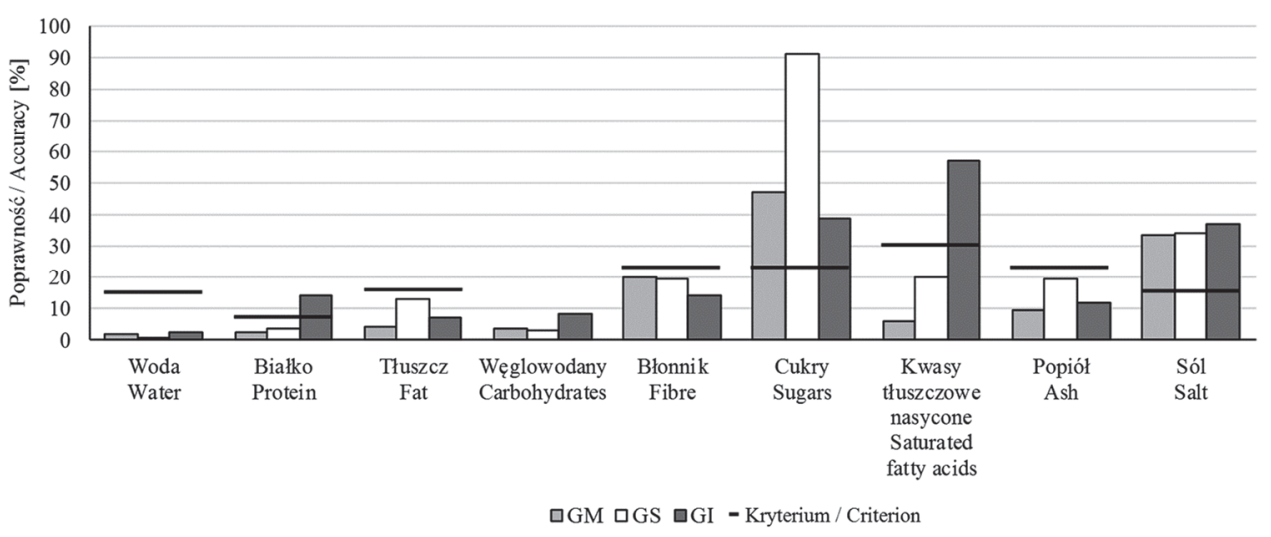

Rys. 1. Poprawność NIR i kryteria oceny użyteczności metody do pomiaru wartości odżywczej badanych rodzajów produktów

Fig. 1. Accuracy of NIR and assessment criteria of method suitability for measuring nutritional composition of product groups studied

Większość przygotowanych kalibracji NIR (dotyczących wody, tłuszczu, błonnika i popiołu) pozwoliła na uzyskanie pomiarów spełniających zadane kryterium poprawności pomiaru. Białko i kwasy tłuszczowe nasycone również zostały oszacowane z zadowalającą poprawnością w produktach GM i GS. W przypadku węglowodanów nie ustalono kryterium, ponieważ jest to składnik chemiczny uzyskiwany z wyliczeń, niepodlegający walidacji w laboratorium, jednak przy pomiarze NIR badanych rodzajów produktów jego poprawność wynosiła poniżej $10 \%$, zatem również była akceptowalna. W przypadku cukrów i soli nie uzyskano zadowalających wyników poprawności NIR dla żadnego z badanych rodzajów produktów. Duży błąd pomiaru przy analizie tych składników był prawdopodobnie spowodowany małymi ich stężeniami w analizowanych próbkach. Mała zawartość mierzonych składników wiąże się z większą niepewnością pomiaru nie tylko NIR, ale również analiz laboratoryjnych. Być może przy większej liczbie prób o większej zawartości cukrów i soli można by uzyskać zadowalające wyniki również dla tych kalibracji. 


\section{Wnioski}

1. Wykonane kalibracje pozwoliły na poprawny pomiar zawartości wody, białka, tłuszczu, węglowodanów, błonnika, kwasów tłuszczowych nasyconych i związków mineralnych w postaci popiołu dla co najmniej dwóch rodzajów analizowanych produktów.

2. W przypadku cukrów i soli nie uzyskano zadowalających wyników poprawności NIR dla żadnego z badanych rodzajów produktów. Poprawa jakości kalibracji tych składników odżywczych wymaga dalszych badań.

3. Metoda NIR jest dobrą alternatywą dla kosztownych i czasochłonnych laboratoryjnych metod pomiaru wartości odżywczej produktów garmażeryjnych i makaronów. Ponadto nie wymaga ona zastosowania niebezpiecznych substancji chemicznych. Przewiduje się, że zastosowanie aparatów NIR do kontroli jakości wyrobów w przemyśle spożywczym będzie nadal wzrastało.

\section{Podziękowania}

Autorzy niniejszej publikacji dziękuja panu Stanisławowi Kosowi z firmy FOSS za wsparcie merytoryczne dotyczace oprogramowania i sprzętu NIR.

Badania zostaty dofinansowane z Funduszy Europejskich z projektu pt. „Nowe metody badawcze JARS Sp. z o.o." w ramach Regionalnego Programu Operacyjnego Województwa Mazowieckiego 2014 - 2020. Projekt zrealizowany w ramach pierwszej Osi Priorytetowej RPO WM, Działanie 1.2 Dziatalność badawczo-rozwojowa przedsiębiorstw.

\section{Literatura}

[1] Azizian H., Kramer J.: A rapid method for the quantification of fatty acids in fats and oils with emphasis on trans fatty acids using Fourier Transform near infrared spectroscopy (FT-NIR). Lipids, 2005, 40, 855-867.

[2] Bagchi T.B., Sharma S., Chattopadhyay K.: Development of NIRS models to predict protein and amylose content of brown rice and proximate compositions of rice bran. Food Chem., 2016, 191, 21 27.

[3] Blanco M., Villarroya I.: NIR spectroscopy: A rapid-response analytical tool. TrAC., 2002, 21, 240250.

[4] Cama-Moncunill R., Markiewicz-Keszycka M., Dixit Y., Cama-Moncunill X., Casado-Gavalda M.P., Cullen P.J., Sullivan C.: Multipoint NIR spectroscopy for gross composition analysis of powdered infant formula under various motion conditions. Talanta, 2016, 154, 423-430.

[5] Deng Y., Wang Y., Zhong G., Yu X.: Simultaneous quantitative analysis of protein, carbohydrate and fat in nutritionally complete formulas of medical foods by near-infrared spectroscopy. Infrared Phys. Technol., 2018, 93, 124-129. 
[6] Dixit Y., Casado-Gavalda M.P., Cama-Moncunill R., Cama-Moncunill X., Markiewicz-Keszycka M., Cullen P.J., Sullivan C.: Developments and challenges in online NIR spectroscopy for meat processing. Compr. Rev. Food Sci. Food Saf., 2017, 16, 1172-1187.

[7] Encina-Zelada C., Cadavez V., Pereda J., Gómez-Pando L., Salvá-Ruíz B., Ibañez M., Ibanez M., Teixeira J.A., Gonzales-Barron U.: Estimation of Proximate Composition of Quinoa (Chenopodium quinoa, Willd.) Flour by Near-Infrared Transmission Spectroscopy. Int. Congress on Engineering and Sustainability in the XXI Century, Algarve-Faro, Portugal, 2017, October, pp. 227-235.

[8] Firmani P., La Piscopia G., Bucci R., Marini F., Biancolillo A.: Authentication of P.G.I. Gragnano pasta by near infrared (NIR) spectroscopy and chemometrics. Microchem. J., 2020, 152, \#104339.

[9] Jia B., Yao Y., Liu J., Guan W., Brennan C.S., Brennan M.A.: Physical properties and in vitro starch digestibility of noodles substituted with tartary buckwheat flour. Starch-Starke, 2019, 71, \#1800314.

[10] Huang H., Yu H., Xu H., Ying Y.: Near infrared spectroscopy for on/in-line monitoring of quality in foods and beverages: A review. J. Food Eng., 2008, 87, 303-313.

[11] Huang Y., Rogers T.M., Wenz M.A., Cavinato A.G., Mayes D.M., Bledsoe G.E., Rasco B.A.: Detection of sodium chloride in cured salmon roe by SW-NIR spectroscopy. J. Agric. Food Chem., 2001, 49, 4161-4167.

[12] Kays S.E., Barton F.E.: Near-infrared analysis of soluble and insoluble dietary fiber fractions of cereal food products. J. Agric. Food Chem., 2002, 50, 3024-3029.

[13] Lucarini M., Durazzo A., Kiefer J., Santini A., Lombardi-Boccia G., Souto E.B., Romani A., Lampe A., Ferrari Nicoli S., Gabrielli P., Bevilacqua N., Campo M., Morassut M., Cecchini F.: Grape seeds: Chromatographic profile of fatty acids and phenolic compounds and qualitative analysis by FTIR-ATR spectroscopy. Foods, 2019, 9(1),\#10.

[14] Manley M.: Near-infrared spectroscopy and hyperspectral imaging: Non-destructive analysis of biological materials. Chem. Soc. Rev., 2014, 43, 8200-8214.

[15] Megazyme: Total Dietary Fibre Assay Kit [on line]. Megazyme. Dostęp w Internecie [2.01.2020]: https://secure.megazyme.com/Total-Dietary-Fiber-Assay-Kit

[16] Neves M.D.G., Poppi R.J., Siesler H.W.: Rapid determination of nutritional parameters of pasta/sauce blends by handheld near-infrared spectroscopy. Molecules, 2019, 24(11), \#2029.

[17] Pasquini C.: Near infrared spectroscopy: A mature analytical technique with new perspectives A review. Anal. Chim. Acta, 2018, 1026, 8-36.

[18] PN-A-04018:1975. Produkty rolniczo-żywnościowe. Oznaczanie azotu metodą Kjeldahla i przeliczanie na białko.

[19] PN-A-82100:1985. Wyroby garmażeryjne. Metody badań chemicznych.

[20] PN-A-82109:2010. Mięso i przetwory mięsne. Oznaczanie zawartości tłuszczu, białka i wody. Metoda spektrometrii transmisyjnej $\mathrm{w}$ bliskiej podczerwieni (NIT) $\mathrm{z}$ wykorzystaniem kalibracji na sztucznych sieciach neuronowych (ANN).

[21] PN-EN 13804:2013-06. Artykuły żywnościowe. Oznaczanie pierwiastków śladowych i ich form chemicznych. Uwagi ogólne i wymagania szczegółowe.

[22] PN-EN 15948:2015-05. Ziarno zbóż. Oznaczanie wilgotności i zawartości białka. Metoda z zastosowaniem spektroskopii w bliskiej podczerwieni w całym ziarnie.

[23] PN-EN ISO 12966-4:2015-07. Oleje i tłuszcze roślinne oraz zwierzęce. Chromatografia gazowa estrów metylowych kwasów tłuszczowych. Część 4: Oznaczanie techniką kapilarnej chromatografii gazowej.

[24] PN-ISO 1444:2000. Mięso i przetwory mięsne. Oznaczanie zawartości tłuszczu wolnego.

[25] Rozporządzenie Parlamentu Europejskiego i Rady (UE) Nr 1169/2011 z dnia 25 października 2011 r. w sprawie przekazywania konsumentom informacji na temat żywności, zmiany rozporządzeń Parlamentu Europejskiego i Rady (WE) nr 1924/2006 i (WE) nr 1925/2006 oraz uchylenia dyrektywy Komisji 87/250/EWG, dyrektywy Rady 90/496/EWG, dyrektywy Komisji 1999/10/WE, 
dyrektywy 2000/13/WE Parlamentu Europejskiego i Rady, dyrektyw Komisji 2002/67/WE i 2008/5/WE oraz rozporządzenia Komisji (WE) nr 608/2004. Dz. UE L 304, ss. 18-63, z 22.11.2011, z późn. zm.

[26] Wang T., Rodriguez-Saona L.E.: Rapid determination of sugar level in snack products using infrared spectroscopy. J. Food. Sci., 2012, 77, 874-879.

[27] Wójcicki K.: Applying NIR spectroscopy to evaluate quality of whey protein supplements available on the Polish market. Żywność. Nauka. Technologia. Jakość, 2018, 2 (115), 59-70.

[28] Zielińska H., Zieliński K.: Spożycie żywności w Polsce. Tendencje i determinanty zmian. Nierówności Społeczne a Wzrost Gospodarczy, 2004, 5, 105-118.

\title{
APPLICATION OF NEAR INFRARED SPECTROSCOPY TO ANALYSE NUTRITIONAL VALUE OF DELI PRODUCTS AND PASTAS AVAILABLE ON POLISH MARKET
}

\author{
S u m m a r y
}

The objective of the research study was to assess the suitability of near infrared spectroscopy (NIR) for the analysis of nutritional value of deli products and pastas available on the Polish market. The assessment was made on the basis of the comparison between the NIR and laboratory analysis results of nutritional values. The NIR instrument was calibrated for the three groups of products: 1) deli products with meat, such as croquettes, pierogi (dumplings with various fillings), pyzy (potato dumplings), tortillas; 2) deli products with quark, such as pierogi with quark and ruskie pierogi (dumplings with quark and potato), crepes with quark, leniwe (sweet dumplings), knödels (fruit dumplings); 3) other deli products such as potato dumplings, steamed dumplings, crepes without a filling and also cooked pasta. The calibrations were performed by correlating the NIR spectra with the results of laboratory analyses for each product group and chemical components.

It was shown that at least for two analysed groups of products, the measurement quality was acceptable as regards the following chemical components: water, protein, fat, carbohydrates, mineral components in the form of ash, fibre and saturated fatty acids. No satisfactory results were obtained for sugars (monoand disaccharides) and salt $(\mathrm{NaCl})$. The low accuracy of NIR measurements of those chemical components could result from a low or insufficiently differentiated, substance-specific level of the measured substance in a given group of the products or from a low interaction of that compound with the near-infrared radiation, which makes it difficult to detect it. Based on the results presented, it can be concluded that the NIR method is suitable for the accurate prediction of the majority of chemical components, which make up the nutritional value and which should be stated on the label of deli products and pastas. It can be a good alternative to cost and time-consuming laboratory analyses.

Key words: near-infrared spectroscopy (NIR), nutritional value, deli products, chemometrics, NIR calibration 